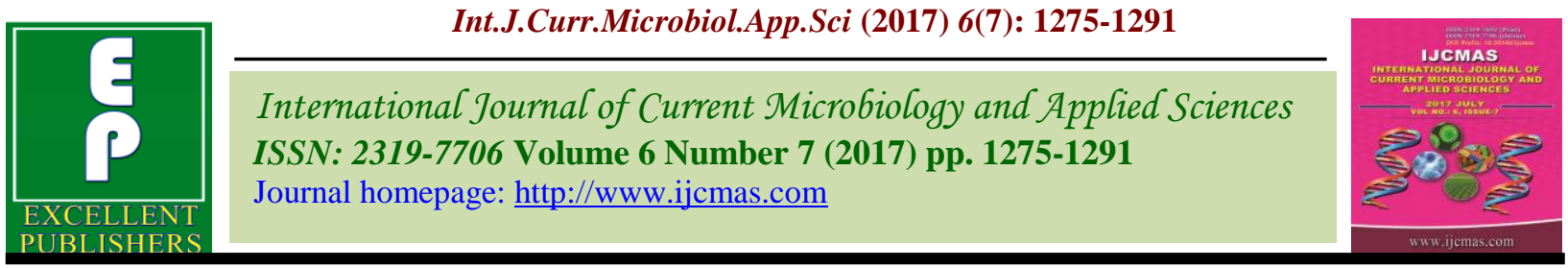

Review Article

https://doi.org/10.20546/ijcmas.2017.607.155

\title{
Banana Bunch Covers for Quality Banana Production - A Review
}

\author{
D.T. Santosh*, K.N. Tiwari and Raja Gopala Reddy \\ Agricultural and Food Engineering Department, Indian Institute of Technology, \\ Kharagpur - 721 302, West Bengal, India \\ *Corresponding author
}

\begin{tabular}{|c|c|}
\hline & A B S T R A C T \\
\hline & \multirow{4}{*}{$\begin{array}{l}\text { India leads the world in banana production, producing around } 18 \% \text { of the worldwide crop } \\
\text { of } 139 \text { million metric tonnes. In spite of this, its exports are minimal for various reasons. } \\
\text { External appearance, internal and market quality of bananas are influenced by several } \\
\text { factors, including production practices. Banana bunch cover is a physical protection } \\
\text { method which will improves the visual quality of fruit by promoting skin colouration and } \\
\text { reducing blemishes, but can also change the micro-environment for fruit development, } \\
\text { which can have several beneficial effects on internal fruit quality. Bunch cover can also } \\
\text { reduce the incidence of disease, insect pest and/or mechanical damage, sunburn of the } \\
\text { skin, fruit cracking, agrochemical residues on the fruit, and bird damage. Bunch covering } \\
\text { is laborious and its benefit cost ratio must be investigated in order to promote adoption of } \\
\text { the method in much of the World. Few researches have been conducted studies on the } \\
\text { effects of banana bunch covers in different parts of the World, but the results have not } \\
\text { been compiled. We have therefore attempted to compile all the scattered information on } \\
\text { banana bunch cover to assist researchers and extension personnel working in this area. }\end{array}$} \\
\hline $\begin{array}{l}\text { Banana bunch } \\
\text { covers, } \\
\text { Promoting skin } \\
\text { colouration, } \\
\text { Quality banana } \\
\text { production. }\end{array}$ & \\
\hline Article Info & \\
\hline $\begin{array}{l}\text { Accepted: } \\
\text { 17 June } 2017 \\
\text { Available Online: } \\
\text { 10 July } 2017\end{array}$ & \\
\hline
\end{tabular}

\section{Introduction}

Banana (Musa sapientum) is an important fruit crop in India. Bananas are grown in more than 150 countries, producing 105 million tonnes of fruit per year. The global production of banana is around 102028, 17 thousand tons of which India contributes $29.19 \%$. In spite of this, its exports are minimal for various reasons. External appearance, internal quality and market quality of bananas are influenced by several factors, including pre-harvest production practices. The external appearance includes key attributes such as colour, shape, size and freedom from defects. The internal attributes such as taste, texture, sweetness, aroma, acidity, flavour, shelf life and presumed nutritional values of the fruit are important in ensuring repeat buys for sustained repeat purchase (Hewett, 2006; Shewfelt, 2009). The physical appearance of the peel is especially important in the highly competitive export markets and in some local supermarkets. Buyers in these prime markets require consistent supplies of uniform coloured fruit with blemish-free peels.

Flowering and fruiting times depend upon banana variety. The banana plant needs 6 to 8 months to produce a single flower stalk. It takes an additional four to six months for the fruits to ripen. This is a long time to wait for delicious banana fruits, and it would be a shame to lose them to birds, insects or elemental damage. Wind is an ever-present threat to banana growers worldwide. It causes 
surface scarring of the peel in several ways. Blowing dust and debris which hits the delicate outer skin causes cellular damage and subsequent fruit scarring. Also, the blowing of adjacent leaves and rubbing of leaf petioles onto the developing bunch can impart considerable physical injury and abrasion damage to the fruit peels (Anon, 2003). Preharvest insect feeding is also a main cause of peel damage to bananas. Growers in regions with a high population of peel feeding insects have great difficulty in producing blemishfree fruit. Many growers suffer a significant loss in market quality of their fruit due to the pre-harvest feeding of these insect pests.

To prevent the losses caused by biotic and a biotic factors, several practices are becoming popular throughout the World (Sharma, 2009). The development of alternative techniques to improve the appearance and quality of fruit and to reduce disease and insect infestations is becoming increasingly important as consumer anxiety over the use of man-made agro-chemicals and environmental awareness increases. Thus, more emphasis is being placed on reducing the use of pesticides to ensure worker safety, consumer health, and environmental protection (Sharma et al., 2009). Farmers have been addressing these issues for some time with bunch cover or bag which protects the fruit from insect attacks and at the same time allows water, air to pass through, all at an affordable cost. These bags are mainly used to improve fruit production and quality, especially fruit intended for the export markets.

Banana fruit protection bags also know as banana ripening bags, banana bunch covers, banana covers and crop covers for bananas are used throughout the commercial banana growing areas of the world (Muchui et al., 2010). Bagging is a physical protection technique, commonly applied to many fruit, which not only improves their visual quality by promoting peel colouration and reducing the incidence of fruit cracking, but can also change the microenvironment for fruit development (Fan and Mattheis, 1998), which can have multiple effects on internal fruit quality. The bags are made in various colours, and designs, however with the ultimate aim of suitability for use in banana growing regions (Jannoyer and Chillet, 1998; Muchui et al., 2010). Commercial producers use expensive plastic banana bunch bags that often are impregnated with insecticides to protect banana bunches. Some of the farmers were using pesticides over bunches to maintain pest freeness and to get rid of blemishes.

Bunch covers provide protection to the fruit surface against pathogens, wind damage, leaf and petiole scarring, dust, light hail, sunburn, bird feeding, and handling damage during harvest and transport. Bunch covers have also been used to protect bunches from low temperatures, especially in temperate countries (Harhash and Al-Obeed, 2010). The bagging technique has also been used on several fruits, to protect them from low temperatures (Mohamed and Al-Qurashi, 2012) and has been shown to reduce winter stress under optimal condition, which resulted in early fruit maturation (Muchui et al., 2010). Export quality includes appealing skin colour, reduced sunburn, reduced fruit splitting, and increased finger length and bunch weight among others (Amarante et al., 2002). A significant reduction in peel surface damage from insect pests may be obtained by covering the banana bunch shortly after pollination. The chaffing of fruit from leaves during growth has also been reported to be eliminated by bunch covers (Weerasinghe and Ruwapathirana, 2002). In addition, the incidence of postharvest anthracnose disease has been shown to be significantly less on fruit from sleeved bunches. The net effect of bunch cover use is better fruit quality and increased marketable yield. Banana bunch 
covers allow for production of high quality banana fruits that are not bruised, and hence have acceptable visual appearance. Consumers use visual quality to purchase fresh produce (Shewfelt, 2009). Market returns for bananas in international markets are generally greatest for large fruit that are blemish-free (Johns, 1996).

\section{History of banana bunch covers}

Bunch covering is an ancient practice. For centuries, old banana leaves have been wrapped around maturing bunches. In 1936 it was demonstrated that covering bunches with hessian protected them against winter chilling and improved fruit quality. Later, paper bags were used to a limited extent. In 1955, Queensland led the trend toward adoption of tubular poly vinyl chloride (PVC), then the cheaper blue polyethylene covers after trials produced record bunches. At first, the transparent covering caused sunburn on the first two hands and it was found necessary to protect these with newspaper before pulling on the plastic sleeve. The use of plastic covers became standard practice not only in Australia but in Africa, India and the American tropics. In 1963, growers were turning to covers made of High Wet Strength (formaldehyde-treated) kraft paper which was already in use for garbage bags. These bags were easily stapled at the top, prevented sunburn, resisted adverse weather, and were reusable for at least another season. Some growers still prefer the burlap. It is cautioned that the cover should not be put on until the bracts have lifted from the fruits (about 21 days after "shooting") so that the young fingers will be firm enough to resist the friction of the cover. Although several colours gave excellent results, the banana industry standardised on blue for many years. In more recent years, blue, green, yellow and clear, with and without silver sides, have been used. The different colours are used as an aid in estimating bunch maturity and the silver sides reduce sunburn.

\section{Advantages of banana bunch covers}

\section{Microclimate}

The cover creates a microclimate that maintains a high temperature and prevents winter damage. Depending on the study, the temperature over a 24-hour period increases on average by $0.5^{\circ} \mathrm{C}$ inside the cover (Ganry, 1975) and can increase by $7^{\circ} \mathrm{C}$ in the warmest hours (Soto, 2010). This microclimate can reduce by many days the flower-to-harvest interval (between 4 to 14 days depending on the type of cover and the environmental conditions) and increase bunch weight. Johns and Scott (1989) reported on microclimate of banana bunch covers. During summer, average air temperatures inside bunch covers will be $3-6{ }^{0} \mathrm{C}$ above ambient. Differences were smallest at dawn, and greatest in the late afternoon. During winter bunch cover temperatures were $1-2{ }^{0} \mathrm{C}$ above ambient. Relative humidity was also influenced by covering, with bunch cover humidity remaining above 95\%, carbon dioxide concentrations inside covers, when bunches were harvested averaged $8 \%$, but varied widely from $<1$ to $42 \%$. Oxygen concentrations averaged 10\% (range 2-19\%), were lowest during the warmer part of the year, and were inversely related to $\mathrm{CO}_{2}$ levels. Building up of high relative humidity inside the banana bags can however be reduced with use of perforated bags (Anon., 2003; Muchui et al., 2010), ultimately preventing multiplication of fungi. Sizes of the holes should also vary with climatic conditions within production areas. Besides effect of presence of holes on changes in humidity and temperature inside bunch covers, colour of the covers also plays a role in micro environment characteristics. Indeed bagging has been shown to reduce winter stress under optimal 
condition which resulted in early fruit maturation (Jia et al., 2005). This is due to enhanced physiological and metabolic activities provided by the microclimate created by bagging (Johns and Scott, 1989).

\section{Temperature}

A bunch emerging in November takes six months or more to mature, while one emerging in March takes only three months. So temperature has a big influence on the rate of fruit growth, hence the use of bunch covers, which are thought to warm the fruit, thereby increasing growth rate. Bunch covers also reduce the gradient of temperature across the bunch, and fruit from covered bunches is more uniform than that from uncovered bunches.

Temperatures below 12 to $13{ }^{\circ} \mathrm{C}$ can cause under peel discolouration which indicates that the fruit was subjected to low temperatures during the development stages (Hailu et al., 2013). Fruit with severe under peel discolouration will not ripen to a bright yellow colour and will therefore not be acceptable to export markets (Snowden, 2010). The low temperature also retards growth, extending the period between flowering and the harvest of the fruit. For centuries, old banana leaves have been wrapped around maturing bunches (Heenan 1973). It was later shown that banana bunches covered with hessian were protected against winter chilling which improved fruit quality (Turner, 1984).

Different bags were used for bunches developed during winter and summer. The use of non-perforated blue or white polyethylene bags with a thickness of 30-35 micron have increased temperatures inside the bag and shorten the development cycle of winter bunches (Robinson and Nel, 1982). White perforated bags have been used in summer and are ideal for hot humid conditions Reflection of direct solar radiation, which results in lower temperature inside the bunch, has resulted in better green life. Transparent and perforated polythene sheets with $2 \%$ (during cool season) $-4 \%$ (during summer season) ventilation may be used to cover bunches. It increases the temperature around developing bunch and also helps in early maturity.

\section{Sunburn}

High air temperatures (usually greater than $38^{\circ} \mathrm{C}$ ) and bright sunshine are associated with sunburn damage on exposed fruit, especially on the top hands of the bunch. Care is needed if bunch covers are used. Sunburn can be avoided if a protective covering such as paper is placed between the fruit and the cover, or covers with a reflective coating on one side are used (Turner, 2013). The yields are much less during the warmer months and special care needs to be taken to avoid sunburn under covers during these warmer months. This involves the use of reflective silver covers and pulling down a leaf over the cover. Perforated covers are commonly used to reduce sunburn damage for export production overseas (Daniells and Lindsay, 2005).

\section{Pest and diseases}

In fruit such as banana, mango, apple, and date, birds are major pests at the fruit-ripening stage and cause considerable losses. Fruit bagging may be the best practice to produce bird-damage-free fruit, if used at the right time of fruit development. Fruit bagging has helped to reduce bird damage in various fruit (Harshash and Al-Obeed, 2010). The use of polyethylene bags on bunches, was advocated as a control measure of diseases in Cameroon, India and Palestine (Jones, 2000). Most banana bunch pests cause superficial peel damage which does not affect the eating 
quality of the fruit. The domestic market in India allows a degree of tolerance for superficial damage caused by insects. However, external blemishes caused by bunch pests are totally unacceptable for the discerning export market, where quality standards are strict. Several insects are primarily responsible for peel damage, including thrips, fruit scarring beetles, and the tar honey wasp. Banana thrips (Chaetanaphothrips orchidii) can be controlled with bunch covers in 2-3 weeks after formation of fruits (Stover and simmonds, 1987). In addition bunches were protected against the pests and diseases such as thrips, beetles, pitting, anthracnose, tip end rot, cigar end rot, brown spot and diamond spot (Amani and Avagyan, 2014). Early bunch covering protects the fruit from scarring caused by nectar-feeding birds and bats during the flowering phase. Applying heavier gauge bunch covers $(150 \mathrm{~mm})$ before any bracts lift on the bunch can overcome this problem.

\section{Thrips}

Several different species of thrips can cause damage to banana fruit. Thrips are small insects, about 1 to $2 \mathrm{~mm}$ long, that occur on the fruit as the bunch is emerging and the bracts lift. Red rust thrips (Chaetanaphothrips spp.) cause rust-colored blemishes to form on the fruit due to feeding of nymphs and adults. They feed on the soft skin of the immature fruit, usually on the hidden surfaces between the closely packed fingers, especially in areas where the fingers are touching. The top hands are usually the most seriously affected. The damage should not be confused with maturity bronzing, which occurs on the exposed outer curve of the fruit and is not confined to areas where the fingers are touching. In severe cases the fruit develops longitudinal cracks and damage may extend over most of the fruit surface. Although the damage does not reduce the eating quality of the fruit, it negatively affects the external appearance and market value. Flower thrips (Frankliniella spp.) are common and causes a small raised pimple, capped by a black spot, to develop on the fruit surface. This is due to the adult female laying its eggs in the skin of soft immature fruit. Most species of thrips are effectively controlled by applying chlorpyrifosimpregnated bunch covers soon after bunch emergence.

The banana rust thrips, Chaetanophothrips orchidii; syn. C. signipennis, stains the peel, causes it to split and expose the flesh which quickly discolors. The pest is usually partially controlled by the spraying of dieldrin around the base of the pseudostem to combat the banana weevil borer, because it pupates in the soil. Another measure has been to treat the inside of polyethylene bunch covers with insecticidal dust, especially Diazinon, before slipping them over the bunches. A great improvement is the introduction of polyethylene bags impregnated with $1 \%$ of the insecticide dursban, eliminating the need for dusting. Bunches enclosed in these bags have been found $85 \%$ free of attack by the banana rust thrips. The bags retain their potency for at least a year in storage.

\section{Fruit scarring beetle}

The fruit scarring beetle (Colaspis hypochlora), is a common insect pest in most of the banana producing areas. Occurrence of this pest is usually high during the rainy season. Adult beetles feed on the fruit peel causing a localized scarring of the tissue in the damaged area. A clear fluid, which eventually turns black, is exuded from wounds. The wounds are only superficial and do not extend to the edible portion of fruits. Symptoms of fruit damage include raised lesions and scars along the peel surface, especially along the midrib area of the fruit. 
This pest invades the bunches when the fruits are very young. The adherence to proper cultural practices will greatly reduce the incidence of this pest. In addition, insect pressure can be reduced by covering the developing banana bunches with chlorpyrifos impregnated bunch cover.

\section{Fungal diseases}

The study was conducted by Amani and Avagyan (2014), to investigate the effect of bunch covering on fungal diseases and postharvest quality of tissue cultured banana fruits using cv. Dwarf Cavendish as the test variety in Iran. The results showed that the fungus like Pyricularia grisea, Musicellium theobromae, Cercospora hayi, Fusarium moniliforme, $F$. solani and $F$. pallidoroseum were isolated from samples. Symptoms of pitting, tip end rot, cigar end rot, brown spot, diamond spot and Sunburn were observed in without bunch cover treatment. Finally, using polyethylene cover is recommended treatments for decreasing of diseases damage and improving the quality characters of fruits.

\section{Recycling}

Many plantations reuse or recycle the plastic covers. When the workers select the bunches to be harvested, they lower them and carefully lift the bag in order to avoid damaging it. The plastic covers are put in a large bag and taken to a collection centre, where they are sorted. Those that can be reused are pre-washed in water and soap and transferred to a tank for a long period to remove stains and debris. They are then wrung to remove excess water and hung on a line for drying. Once dry, they are stored in large bags for 4 weeks before being reused. The plastic covers are reused 3 to 4 times, after which they are sent to a plastic recycling facility to be turned into corner boards (edge protectors).

\section{Mixed ripening}

"Mixed ripe" is the term given to fruit forwarded to markets in a green condition but some of which has begun to ripen by the time it gets there. The condition causes difficulties in ripening and marketing and reduces returns to growers. As a banana grows it becomes more mature. This maturity is related both to the size and age of the fruit. Bunch covers would influence mixed ripe if they changed the relationship between growth and maturity. For example, fruit of similar size may be more mature in a covered bunch.

\section{Disadvantages of bunch covers}

Although the positive benefits of bunch cover application typically far outweigh the undesirable effects, it is important to point out several possible negative consequences. The use of non-perforated bunch covers in hot, humid climates may damage the bunch physiologically due to overheating, rotting, and premature ripening. In addition, insect pests may proliferate inside non-insecticide treated bunch covers. Another negative consequence of ineffective bunch covers is the economic loss due to the extra cost of the material and the labor needed for application. In sub tropical countries, the negative consequences are avoided by using perforated bunch covers for aeration and cooling, and insecticide-impregnated covers for pest control.

\section{Types of banana covers}

The covering of bunches has become a cultural practice in commercial banana production. The recommended type of bunch cover varies according to environmental conditions. Bunch covers are typically made of thin plastic (low density polyethylene; 5 to 40 microns) and are 81.3 to $91.4 \mathrm{~cm}$ (32 to 36 inches) wide and range in length from 1 to 1.5 
meters (3.3 to 5 feet). The thin bunch covers are designed to be used only once. The thicker ones can be re-used, but the removal process is time consuming and it is difficult to avoid damaging the plastic. Commercially available bunch covers generally are coloured white or translucent blue. The plastic may also be coloured silver to reflect heat.

\section{Thickness}

The thickness of the cover does not affect its efficiency. It mainly has an impact on its cost and the environment. It also depends on the local wind and temperature conditions. The thickness is generally between 12 and $25 \mu \mathrm{m}$. Studies have reported that above $130 \mu \mathrm{m}$, the covers offer a better protection against the cold but is can cause malformations and sunburns. Thicker non-perforated types are best suited for cooler sub-tropical growing areas where heat build-up inside the cover is desired. In tropical growing environments the thicker non-perforated bunch covers usually result in excessive heat and humidity build-up inside the cover. Thin perforated bunch covers which allow for aeration inside the cover are the preferred type for tropical growing areas. A banana bunch cover thickness micron plays a very important role in influencing temperatures inside the bag within the bunch. Economically, it is better to use thinner bunch covers as damage is bound to occur and plastic damaged not being able to be re-used again. The longevity of polyethylene bunch covers for bananas in relation to thickness was evaluated by Trochoulias (1975). The author reported that four thicknesses of blue polyethylene bunch cover $(0.038,0.050,0.075$ and $0.100 \mathrm{~mm})$ for bananas were compared for longevity under field conditions. Blue polyethylene banana bunch covers $0.075 \mathrm{~mm}$ thick lasted longer than either 0.050 or $0.100 \mathrm{~mm}$ film. The $0.100 \mathrm{~mm}$ covers suffered from a high incidence of disintegration due to bag chemical composition.

\section{Colour}

Bunch covers of various colours and conditions (perforated and non-perforated) have been extensively used in both tropical and subtropical banana growing countries with the aim of improving yield and quality (Robinson, 1996). Commercially available bunch covers generally are colored white or translucent blue. The plastic may also be colored silver to reflect heat. The use of covers of various colours may also be dependent on seasons (Stevenson, 1976). The use of various colours in different seasons, climate or regions has shown their different performance capabilities towards banana physiological growth. Photosynthetically active radiation (PAR) which is responsible for light intensity required in growth and development becomes filtered through various bunch cover colour designs. Transparent covers let in more light than blue or green covers. Various colours have been tested (pink, green, blue, white and black) as well as the transparency of the cover. The colour acts as a filter of photosynthetically active radiation (PAR), the wavelengths between 400 and $700 \mathrm{~nm}$ that are used during photosynthesis. The industry usually uses blue or transparent covers. Blue covers let in $73 \%$ of the wavelengths in the PAR, whereas transparent ones let in 93\%. Nevertheless, blue covers produce heavier bunches because it lets in the heat without causing burns because it blocks UV rays. Blue covers also do not harden the peel one of the disadvantages of bunch covers. Some transparent covers treated to block ultraviolet and infrared rays also perform as well as blue covers.

Cuneen and McEntrye (1988) evaluated whether the colour of banana bunch covers has an effect on the yield of bananas and the climate inside the bag within the cover bunch. Coloured bags are used to cover bunches for several reasons, that is to reduce the time 
between flower emergence (Galan Sauco, 1992) and early harvesting, to improve banana quality and quantity (Robinson and Nel, 1982), as protection to against injuries caused by solar radiation or by pests or mechanical injuries (Soto, 2010). From the studies conducted by Cuneen and McEntyre (1988) with different coloured plastic bags (green, blue, black, orange, blue/silver and clear/silver) enclosed in a wire frame indicated that during the day temperatures inside the bag were $10^{\circ} \mathrm{C}$ higher than the outside air temperature and that during the night the temperature inside the bags fell slightly below the outside temperature. The clear/silver bag resulted in the highest day time temperature increase and the black bag the lowest increase. In studies using the bags as bunch covers, no significant differences in yields and quality were found for the different coloured bags, although yields were highest for bunches inside the clear silver bags (Cuneen and McEntyre, 1988) it was suggested that the clear/silver bags may be of value during the winter period.

\section{Perforations}

The presence of holes is important to prevent the multiplication of fungi. In the absence of perforations, the relative humidity inside the cover is too high. The size of the holes varies: $12.7 \mathrm{~mm}$ every $76 \mathrm{~mm}, 6 \mathrm{~mm}$ every $10 \mathrm{~cm}, 3$ $\mathrm{mm}$ or micro-perforations.

\section{Transparent bag}

Transparent covers treated to block ultraviolet and infrared rays. These transparent bunch covers with specific UV and IR permeability properties were found to allow better light and temperature conditions for banana growth (Jannoyer and Chillet 1998). Transparent polyethylene can be used only under high density planting systems when sunscald is not a problem; otherwise blue bags have been very effective in protecting bunches from sunscald (Choudhury et al., 1997). Trever (2003) reported that sun scorches were observed when transparent polyethylene was used as a bagging material for banana.

\section{Blue polyethylene bags}

Banana production regions mostly use blue covers as they let in heat without causing sun scald (Muchui et al., 2010), because it blocks UV rays. Blue Polyethylene bags used to improve banana's quality, appearance and protect from birds and pests. These bags allow faster \& more trustworthy harvest with adequate ripening of the banana. These also protect from external natural conditions (wind, rain, sun damage, etc.) and prevent mechanical injuries (Marks and Scratches).

\section{Half blue and half silver plastic bags}

These bags are half blue plastic and half silver to reflect heat and are used around the world with the silver colour facing the sun and the blue side closest to the "trunk". During cool months face the blue face north to increase heat and during warmer months face the silver side north to reduce heat inside helping to maintain a constant temperature. These bags are to protect the fruit from bird, wind and sun damage, improve its quality and increase the yield. The bag comes as a tube which slides up the bunch and ties loosely only at the top and is left open at the bottom, as this allows air movement and prevents possible overheating in the bag. Cut off the flower bell $100 \mathrm{~mm}$ below the last hand to increase fruit size. $1200 \mathrm{~mm} \times 730 \mathrm{~mm}$.

\section{All season bunch cover}

The all season bunch cover has been developed and patented as a solution to Australia's harsh climatic growing conditions to provide the ultimate protection in the 
cultivation of banana plantations. Use of the ALL SEASON bunch covers ensure that bananas develop evenly, from top to bottom and back to front. The following special features ensure that your banana bunches have the best protection and productivity all year round. All season covers use a tough blend of polymers and contain 50\% more UV protective additive than any other cover on the market. In addition, the all season plastic film contains diffusing additives to ensure that as the light passes through the film, it is "scattered" in all directions. This feature reduces the heating effect experienced by direct sunlight and allows light to reach all parts of the bunch. Unlike any other cover on the market, one and a half sides of the cover are printed, in reflective, silver ink to ensure the bunch receives constant protection from direct overhead sunshine.

\section{PP non-woven skirting bag}

Polypropylene spun bond non woven fabric banana bunch cover bag is a kind of agriculture fabric use as banana cover $\&$ fruit cover crop cover and known as pp spun bond non woven fabric of UV treated $17 \mathrm{gsm}, 40$ gsm, $60 \mathrm{gsm}, 80 \mathrm{gsm}$ for different kind of use. A protective cover for protection of banana bunch comprises a fibrous Nonwoven fabric exhibiting sufficient vapour permeability to alter or control the ripening of the banana so ensconced while retarding passage of dust and insects.

The Nonwoven is formed with protectionenhancing UV-protective agents. The Nonwoven fabric may be pigmented as desired. The transmittance of light to an agricultural product is known to significantly affect the way that product develops and ripens. The fabric invention provides an improved form of protective cover for banana bunch which is particularly suite for use in controlling the in-situ ripening prior to harvest of the products, and which is configured for economical, and optionally, disposable use. Today the use of Nonwovens has revolutionized the development of very high quality clean spotless bananas around the world and is an established product used by all leading banana growers all over the world, thousands of tones are consumed internationally.

An innovative technical textile product comes in handy in addressing all the needs. It is manufactured from Polypropylene and is available as with width of $1.6 \mathrm{~m}$ and $3.2 \mathrm{~m}$ varying thickness. Seventeen GSM fabrics in white colour, stabilized with UV have been found suitable for this application. The polypropylene spun bonded non-woven fabric crop covers shall conform to the requirements as specified in table 1. It is also available as a tube in roll form. Banana sleeve is laid manually. Since they are very light they must be handled with care. The Fabric must be secured at the top thread. The Fabric is reusable for the next season if not damaged. The tension must be adjusted suitably depending upon the Banana crop.

Advantages with these bags are that they will allow free air and moisture circulation unlike poly bags. This covering will completely block insect damages and pathogen invasion. Besides that, reduced sunlight exposure on the bunch will give very attractive and uniform golden yellow fruits upon maturity during ripening which enhance the marketability. All the hands in the bunch will be more or less uniform in size and also have round shape fruits which are preferred in the market. By adopting these bags, an additional income Rs. 0.75 to 1.00 per $\mathrm{kg}$ of bunch (minimum) could be realized. Totally, an additional net income of Rs. 20000 per acre is possible. Moreover, cost on pesticides and labour required for taking up spray over bunches can also be saved. 


\section{Biodegradable covers}

Biodegradable covers were also developed and tested in various countries, polylactic acid based covers and entirely biodegradable covers that can be buried in the ground.

\section{Timing of application}

Bunch covers are put on as soon after the bell emerges as possible. Where flying foxes and birds are not a problem, the covers can be put on after the bracts that cover the hands have fallen and the flower ends have hardened. Bunch covers should be applied after the bracts covering the hands have fallen, the fingers are curling upwards, and the floral remnants have hardened. Typically, this occurs about 2 to 3 weeks after flowering. The time period from bunch covering until harvest will be slightly over 2 months. Bunch covers reduced the time taken from bunch emergence to harvest by 5-11 days compared with no covering. Very early and early covering gave the largest reductions (Daniells, 1992).

\section{Effect of bunch covers}

The benefits of bunch covers are both physiological and physical. Banana bunch cover has been reported to increase in yield, fruit size and improve fruit quality. Bunches developed in bunch covers were bigger, cleaner, attractive, and dark green in colour. Fruits of bagged bunches showed neither scratches nor blemishes, whereas those of uncovered bunches showed physical injury (Weerasinghe and Ruwanpathirana, 2002).

Choudhury et al., (1996b) reported that using white polyethylene covers was significantly influenced crop duration, particularly days taken from planting to flowering, and flowering to physiological maturity and production per day. Plants treated with a white polyethylene cover matured earlier (430.00 days) compared to the untreated control plants (467.67 days). The same treatment also shortened time (106.33 days) from flowering to physiological maturity in comparison with the untreated control (142.00 days) and economical for controlling damage caused by banana scaring beetle (Basilepta subcostatum), and avoided the use of insecticides thus resulting in higher yields or profits. Crop duration, particularly days taken from flowering to physiological maturity and production per day can be influenced by different bunch cover treatments (Vargas et al., 2010).

According to reports from Daniells (1994) and Johns (2005) increased finger length, higher yield and shorter flower to harvest interval recorded in various studies. Temperatures under the cover were $2^{\circ} \mathrm{C}$ to $6^{\circ} \mathrm{C}$ warmer and during cool times of the year this increased fruit length and hastened fruit filling (harvest duration was 4 to 14 days earlier). Johns and Scott (1989) reported that bagging can influence fruit maturity in banana. In their book, Stover and Simmonds (1987) described the use of polyethylene bags to enhance fruit maturity in banana. Similarly, Rodrigues et al., (2001) reported that the time of harvest in banana plants with covered bunches was 12 days earlier in the first crop. Bunch covers performed the same as in control for summer but in winter the use of transparent material speeded up the filling and harvesting of banana bunches (Johns 1996). Jannoyer and Chillet (1998) evaluated different types of bagging materials and found that bunch bagging decreased exposure to radiation and hence sunscald and reduced inbag temperature. They also found that the number of days from flowering to harvest were reduced, fruit growth was improved and yield was significantly increased in bagged bunches. Shooting-harvest internal was also reduced by 15 days with transparent 
polythene cover. Sealed bunch covers delayed harvest by up to 16 days compared with no covering (Daniells et al., 1992).

Yield (bunch weight, bunch length, number of fingers per bunch, finger length and finger weight) was significantly influenced by bunch cover treatment with the highest bunch weight of $15.25 \mathrm{~kg}$ and yield of 67.78 tonnes per hectare. The highest cost: benefit ratio (1:3.53) was observed in white bunch cover treatment and lowest cost: benefit ratio was low (1:2.8) observed for without bunch cover treatment (Choudhury et al., 1996a). Wearasinghe and Ruwanpathirana (2002) reported that bunch covering, irrespective of the material, had produced bunches which were $32 \%$ heavier than uncovered ones. In contradictory, Rodrigues et al., (2001) reported that polyethylene covers had no effect on banana bunch or total fruit weights.

Weerasinghe and Ruwapathirana (2002) reported that the use of transparent and blue polythene covers enhanced fruit yield by 20 and $16 \%$ respectively over the control (uncovered bunches). The highest harvest index obtained under transparent polythene cover indicated the significance of bunch cover in larger partitioning of nutrients to the developing bunches. The use of sealed covers increased bunch weight by up to $9 \%$. This was due to increased finger length along the entire bunch (Daniells et al., 1992).

Some researchers were found earlier where, for banana $\mathrm{cv}$. robusta grown under high density production system, finger diameter (grade) and weight were significantly increased by polyethylene bunch covers (Reddy, 1989). In South Africa, a 16.5\% increase in 'Williams' bunch mass was recorded due to a $10 \%$ increase in finger length. This may have been due to increased temperatures $\left(0.5^{\circ} \mathrm{C}\right)$ under blue covers that favoured growth (Robinson, 1996).
Choudhury et al., (1996b) reported that the lowest number (10.67) of banana fingers per bunch was obtained using a white polyethylene bunch cover treatment comparing to blue polythene. Bagging bunches with transparent and blue polythene covers will increase the size and weight of fingers Weerasinghe and Ruwapathirana (2002). Banana bunches sealed with polyethylene bags will increase fruit size at harvest (Amarante et al., 2002). The effect of banana bunch covering especially in the tropics has demonstrated inconsistent results on the size of fruit. Double covering increased finger weight of the top six hands by $4 \%$ (Johns, 2006).

Both starch and total soluble solids (TSS) at harvest and during ripening will not get influenced by bunch covers. Unripe bananas have large amount of starch, with a content of 20 to $25 \%$ of pulp of the fruit (Nascimento $e t$ al., 2006). During the climacteric stage, the accumulated polysaccharide is rapidly degraded and most of it is converted into soluble sugars which form a large proportion of TSS in the banana (Seymour et al., 1993). Bagging, however, will not influence the starch formation during banana growth and starch degradation during ripening.

The bunch covers with perforations maintain similar humidity environment during growth and after harvesting comparing to without bunch covering fruits (Amarante et al., 2002). Moisture content of the peel reduced gradually during ripening while that of the pulp increased with ripening. During normal ripening, the banana peel loses water to both the pulp and the atmosphere (Burdon et al., 1994). Fruit surfaces are covered by cuticle covers which restrict water loss through transpiration, also. Fruits from the bagged and control bunches may have had similar cuticle structures (Amarante et al., 2002). 
Bunch covering had significant effect on the pulp/peel ratios of fruits of $\mathrm{cv}$. Williams at harvest and during ripening. It was seen that in bananas, the pulp portion continues to grow even in the later stages of maturation (Nakasone and Paul, 1998), skin colour development and other post-harvest (Turner, 1997). However, this may be due to the different types of bags for bunch covering used, the age of the fruit at covering, fruit and cultivar response, the climatic conditions and also the conditions in which fruit is held pre and post-harvest and all these factors influence fruit quality (Amarante et al, 2002).

Chlorophyll content generally decreased on ripening as the fruits turned yellow. This is as a result of chlorophyll degradation and unmasking of the yellow carotenoids or synthesis of new pigments (Gray et al., 2004). Bunch bagging will not effect on the chlorophyll degradation (Shanmugasundaram and Manavalan, 2002). Anthocyanin accumulation and red colour development of the skin was reduced by bagging (Fan and Mattheis, 1998). This may reflect differences in the type of bagging material and whether perforated or not perforated. Some of the reports have documented that bagging fruit increased skin lightness (Fan and Mattheis, 1998) which shows that bagging has different effects on different fruit cultivars. The difference in effects on colour may also be dependent on type and duration of bagging.

Fruit firmness decreased rapidly during ripening, and gradually after ripening of the fruits. Bagging will not change the peel and pulp properties. However, bagging of fruit will reduce fruit firmness in the postharvest stage for bananas (Berill, 1956). The variable results reported on the effect of bagging on fruit firmness at harvest and postharvest stage may reflect differences in the cultivar, type of bag, duration of cover, storage conditions and methods of testing for fruit firmness.
Effect of bagging may found on both physical and compositional quality of fruits. Narayana et al., (2004) found bagging of bananas coupled with postharvest hot water treatment and storing with ethylene absorbent to be beneficial in extending shelf life. Elsewhere, banana grown under bunch covers had delayed ripening (Johns and Scott, 1989) which may have possibly influenced green life. Fruit bagging has also been shown to adversely affect fruit quality. Sealed plastic covers delayed bunch maturity of bananas (Scott et al., 1971). Banana bunches sealed with polyethylene covers during fruit growth delayed ripening (John and Scott, 1989) probably due to delayed fruit development as a result of modification of atmosphere inside the sealed covers. There was a non-significant reduction of 2-4 days in fruit green life, related to the delay in bunch filling caused by sealed covers (Daniells et al., 1992). The Polypropylene spun bond non woven fabric had the longest green life and the un bagged control had the shortest. There were no significant differences between jute and polyethylene on green life (Elkashif et al., 2005). The findings reported by Stevenson (1976) showed that with summer bunch covering no particular colour of covering material substantially accelerated bunch filling, but in winter the use of transparent material speeded up the filling and harvesting of banana bunches. This raises the need to further evaluate banana bunch covering materials for the warm season for evaluating peel quality (Stevenson, 1976).

\section{Study conducted by PFDC Kharagpur}

The trial was carried out to know the effect of bunch covers on banana production at the existed banana orchard of Precision Farming Development Centre, Agricultural and Food Engineering Department, Indian Institute of Technology, Kharagpur, West Bengal, India during 2013-14 and 2014-15. Twenty four 
bunches of banana cultivar (cv.) Grand naine were randomly selected and tagged. Polypropylene spun bond non woven fabric bunch cover was applied to twelve banana bunches when the flower bracts had hardened and the hands had started to curl upwards. Remaining twelve of the tagged bunches were not covered and they served as control. Yield and yield components were recorded. The second hand of freshly harvested bunch was used to measure the fruit characteristics such as number of hands/ bunch, number of fingers per hand, finger length, finger weight and finger girth (Dadzie and Orchard, 1997). Statistical analyses were performed to significance of the treatment. In order to test the significance of different treatments individually as well as in combinations experimental Student $\mathrm{F}$ test was performed.

Table.1 Specifications as recommended by Bureau of Indian Standards (BIS) for non-woven polypropylene spun bounded banana cover fabric

\begin{tabular}{|c|c|c|}
\hline Characteristics & Unit & Dimension \\
\hline Basic Weight (minimum) & GSM & 17 \\
\hline Thickness & $\mathrm{mm}$ & $0.18 \pm 0.02$ \\
\hline Length (minimum) & $\mathrm{m}$ & 300 \\
\hline Width (minimum) & M & $1.6 \& 3.2$ \\
\hline $\begin{array}{l}\text { Tensile Strength - } \\
\text { Machine direction } \\
\text { b. Cross direction }\end{array}$ & $\mathrm{N} / 5 \mathrm{CM}$ & $\begin{array}{l}35 \\
25\end{array}$ \\
\hline $\begin{array}{l}\text { Trapezoid tear strength - } \\
\text { a. Machine direction } \\
\text { b. Cross direction }\end{array}$ & $\mathrm{N}$ & $\begin{array}{l}25 \\
25\end{array}$ \\
\hline Elongation - MD/CD & $\%$ & 55 to 100 \\
\hline Air Permeability & $\mathrm{M}^{3} / \mathrm{M}^{2} / \mathrm{Min}$ & $350-375$ \\
\hline $\begin{array}{l}\text { UV Stability, retained after } \\
144 \text { h exposure }\end{array}$ & \multicolumn{2}{|c|}{ Strength $>60 \%$ of Original Sample after expose to $200 \mathrm{hrs}$ in UVE } \\
\hline Index puncture resistance & $\mathrm{N}$ & 15 \\
\hline Water absorption capacity & $\%$ & 20 \\
\hline Color & - & White/as per requirement \\
\hline Sleeve Sizes & - & $\begin{array}{c}0.8 \mathrm{M} \text { dia.X1.5M } \\
0.8 \mathrm{M} \text { dia.X1.0M } \\
\text { or in roll form }\end{array}$ \\
\hline
\end{tabular}

Bureau of Indian Standards, 2015 
Table.2 Banana yield parameters and quality parameters as influenced by bunch covers

\begin{tabular}{|l|c|c|c|c|c|c|c|}
\hline \multirow{2}{*}{ Parameters } & \multicolumn{2}{|c|}{ Mean } & \multicolumn{2}{c|}{$\begin{array}{c}\text { Standard } \\
\text { Deviation }\end{array}$} & \multicolumn{2}{c|}{$\begin{array}{c}\text { Coefficient of } \\
\text { Variation, }\end{array}$} & $\begin{array}{c}\text { Significance } \\
\text { level (t test) }\end{array}$ \\
\cline { 2 - 9 } & $\begin{array}{c}\text { Bunch } \\
\text { cover }\end{array}$ & $\begin{array}{c}\text { Without } \\
\text { cover }\end{array}$ & $\begin{array}{c}\text { Bunch } \\
\text { cover }\end{array}$ & $\begin{array}{c}\text { Withou } \\
\text { t cover }\end{array}$ & $\begin{array}{c}\text { Bunch } \\
\text { cover }\end{array}$ & $\begin{array}{c}\text { Without } \\
\text { cover }\end{array}$ & \\
\hline Days to harvesting, days & 323.08 & 335.15 & 12.31 & 9.55 & 3.81 & 2,85 & $*$ \\
\hline Bunch length, cm & 103.23 & 102.23 & 3.76 & 3.65 & 3.65 & 3.56 & NS \\
\hline Bunch weight, kg & 19.98 & 14.87 & 4.48 & 2.73 & 22.43 & 18.36 & $* *$ \\
\hline Number of hands/bunch & 8.75 & 8.67 & 1.06 & 0.98 & 12.06 & 11.36 & NS \\
\hline Number fingers/hand & 17.83 & 18.08 & 2.17 & 2.5 & 12.15 & 13.84 & NS \\
\hline Finger length, cm & 19.53 & 19.21 & 0.83 & 1.54 & 4.28 & 8.0 & NS \\
\hline Finger girth, cm & 13.75 & 12.88 & 0.73 & 0.67 & 5.33 & 5.22 & $* *$ \\
\hline Yield, t/ha & 50.88 & 41.99 & 11.29 & 9.25 & 26.88 & 18.39 & $*$ \\
\hline Fruit Firmness, N & 80.22 & 99.87 & 5.45 & 30.66 & 4.86 & 38.23 & $*$ \\
\hline Pulp peel ratio & 2.07 & 2.12 & 0.18 & 0.27 & 8.88 & 12.67 & NS \\
\hline TSS ${ }^{0}$ Brix & 23.25 & 22.41 & 0.71 & 1.01 & 3.07 & 4.51 & $*$ \\
\hline Reducing sugar (\%) & 12.58 & 12.43 & 0.75 & 1.02 & 5.99 & 8.18 & $*$ \\
\hline Non reducing sugar $(\%)$ & 2.18 & 2.05 & 0.24 & 0.23 & 10.84 & 11.45 & NS \\
\hline
\end{tabular}

* Significant at $\mathrm{p}=0.05 \quad * *$ significant at $\mathrm{p}=0.01 \quad \mathrm{NS}=$ non significant

Banana bunch cover had significant $(\mathrm{p}<0.05)$ effect on days for harvesting and yield of banana (Table 2). At an average 12 days earlier harvesting of banana done under bunch cover treatment. Yield is significantly $(\mathrm{p}<0.05)$ increased under bunch cover treatment in this study. About $9 \mathrm{t} \mathrm{ha}^{-1}$ banana yield increased using bunch cover comparing to control. Yield parameters such as bunch length, number of hands per bunch, number of fingers per hand and finger length were not influenced significantly $(\mathrm{p}>0.05)$ by bunch covers. However, bunch weight and finger girth were significantly $(\mathrm{p}<0.01)$ influenced by bunch covers. Fruit quality parameters such as fruit firmness, total soluble solid (TSS) and reducing sugar were significantly influenced $(\mathrm{p}<0.05)$ by bunch covers at harvest.

In conclusion, post harvest shelf life and market quality of bananas are significantly influenced by pre-harvest production practices. Covering the developing banana bunch in the field shortly after flowering with a perforated bunch cover is usually very effective in reducing both physical and insect damage to the peel. The physical and biochemical properties of the banana fruits were not adversely affected by the bunch covers. Also, the fruits grown covered were more visually appealing as they were clean and had minimal bruises compared to those grown uncovered which implies reduced water usage during post harvest preparation of the fruits.

However, the use of bunch covers should be coupled with proper post harvest handling procedures to ensure that the clean, visually appealing fruits are not bruised during the post harvest period. Such fruits could also be targeted for the export market where they may fetch better prices as the consumer clientele appreciates the visually appealing fruits and are willing to pay more for such fruits. In 
conclusion, pre-harvest bagging of banana bunches reduced physical injury and sunscald, increased yield, increased green life and improved fruit quality.

\section{References}

Amani, M. and Avagyan, G. 2014. Effect of polyethylene bunch cover on fungal diseases control of banana (Musa acuminata L.) in Iran. Int. J. Farming and Allied Sci., Vol., 3(10): 1054-1057.

Amarante, C., Banks, N.H. and Max, S. 2002. "Effect of pre harvest bagging on fruit quality and post-harvest physiology of pears (Pyrus communis)." N. Z. Crop Hort. Sci. J., 30: 99-107.

Anon. 2003. Bunch covers for improving plantain and banana peel quality. National Agriculture Research Institute. Technical Bull., no 4. www.agrinetguyana. org.gymoa.

Berill, F.W. 1956. Bunch covers for bananas. Queensland Agric. J., 82: 435-439.

Burdon, J.N., Dori, S., Lomaniec, E., Marinansky, R. and Pesis. E. 1994. The post-harvest ripening of water stressed banana fruits. J. Hortic. Sci., 69(5): 799804.

Choudhury, H., Chandra, K. and Baruah, K. 1997. Effect of different bunch covers on some biochemical composition of Jahaji (AAA group) Banana. Crop Res, 13(1): 91-97.

Choudhury, H., Chandra, K., and Baruah, K. 1996a. Effect of bunch cover on morphological parameters and yield of banana. Department of Crop Physiology, Assam Agricultural University, Jorhat785013, India. Advances in Plant Sci., 9, pp. 131-137.

Choudhury, H., Chandra, K., and Baruah, K. 1996b. Influence of bunch cover treatments on infestation of fruit scarring beetle and crop duration in Dwarf Cavendish banana. Department of Crop
Physiology, Assam Agricultural University, 785 013, India. Crop-Res., 12 , pp. 50-55.

Cuneen, T., and McEntyre, C. 1988. Does the colour of banana bags have an effect on the yield of bananas and the climate inside the bag? John Paul College, Coffs Harbour, NSW, Australia. Banana Bulletin, 52, pp. 14-15.

Daniells, J.W. and S. Lindsay, 2005. Banana fruit bunch covering. Mhtml: file://cover\% $20 \quad$ all $\$ banana\%20bunch\%20covering.mht.

Daniells, J.W., Lisle, A.T. and O'Farrell, P.J. 1992. Effect of bunch-covering methods on maturity bronzing, yield, and fruit quality of bananas in North Queensland. Australian J. Experimental Agri., 32(1): 121-125.

Daniells, J.W., Lisle, A.T., O'Farrell, P.J. 1992. Effect of bunch-covering methods on maturity bronzing, yield, and fruit quality of bananas in North Queensland. Aust. J. Exp. Agr., 32(1): 121-125.

Debnath, U., Suresh, C.P. and Hasan, M.A. 2001. Bunch Management for Profitable Production of Winter developing banana bunches. Indian J. Horticulture, 58(3): 202-207.

ELkashif, M.E., Elamin, O. M. and Ali, S.A. 2005. Effect of packaging methods and storage temperature on quality and storability of four introduced banana clones. Gezira J. Agri. Sci., 3(2): 185195.

Fan, X. and Mattheis, J.P. 1998. Bagging 'Fuji' apples during fruit development affects colour development and storage quality. Hort Sci., 33: 1235-1238.

Galan Sauco, V. 1992. Los Fruales Tropicales en los Subtropicos II. EI Platano, Madrid, Mundi-Presena, 173 pp.

Ganry, J. 1975. Influence du gainage des régimes du bananier avec une house de polyethyléne sur la temperature des fruits dans les conditions de Neufchateau 
(Guadeloupe. Fruits, 30(2): 735-738.

Gray, J., Wardzala, E., Yang, M., Reinbothe, S., Haller, S. and Paul, F. 2004. A small family of LLSI-related non-heme oxygenases in plants with an origin amongst oxygenic photosynthesizers. Plant Mol. Biol., 54: 39- 54.

Hailu, M. Workneh, T.S. and Belew, D. 2013. "Review on postharvest technology of banana fruit. Review." A. J. Biotechnol., 12: 635-647.

Harshash, M.M. and Al-Obeed, R.S. 2010. "Effect of bunch bagging colour on yield and fruit quality of date palm." American-Eurasian J. Agric. Environ. Sci., 7: 312-319.

Heenan, D.P. 1973. "Bunch covers for bananas in the Northern District Papua New Guinea." Agric. J., 24: 156-161.

Hewett, E.W. 2006. An overview of pre harvest factors influencing post-harvest quality of horticultural products. Int. J. Post harvest Technol. Innovations 1, pp. 4-15.

Hewett, E.W. 2006. An overview of preharvest factors influencing postharvest quality of horticultural products. Intern. J. Postharv. Technol. Innov., 1(1): 4-15.

Jannoyer, M., and Chillet. M. 1998. "Improvement of banana growing conditions with the Katryx ${ }^{\circledR}$ bag." Acta Hort., 490: 127-134.

Johns, G.G. 1996. Effects of bunch trimming and double bunch covering on yield of bananas during winter in New South Wales. Austr. J. Exp. Agric., 36: 229-235.

Johns, G.G. and Scott, K.J. 1989. Delayed harvesting of bananas with 'sealed' covers on bunches. 1. Modified atmosphere and microclimate inside sealed covers., Australian J. Experimental Agri., 29(5) $719-726$.

Jones, D.R. 2000. Diseases of Banana, Abaca \& Enset. CAB International. 544pp.

Mohamed, A. A., Al-Qurashi, A.D. 2012. Gibberellic acid spray and bunch bagging increase bunch weight and improve fruit quality of 'Barhee' date palm cultivar under hot arid conditions. Sci. Hort., 138: 96-100.

Muchui, M.N., Mathooko, F.M. and C.K. Njoroge. 2010. "Effect of perforated blue polyethylene bunch covers on selected post-harvest quality parameters of tissue cultured bananas (Musa spp.) cv. Williams in Central Kenya." J. Stored Products and Postharvest Res., 1: 41-45.

Nakasone, H.Y. and Paull, R.E. 1998. Tropical fruits. CAB International New York.

Narayana, C.K., Krishnan, P. and Satiamoorthy, S. 2004. Effect of bunch covering and postharvest treatments on quality of banana during storage at low temperature. In international congress on Musa harnessing research to improve livelihoods.

Nascimento, J.R.O., Junior, A.V., Bassinello, P.Z., Cordenunsi, B.R., Mainardi, J.A., Purgatto, E. and Lajolo, F.M. 2006. Postharv. Biol. Technol., 40(1): 41-47.

Reddy, S.A. 1989. Effect of bunch covers on bunch maturity and fruit size in high density robusta banana orchards. J. Res. APAU), 17: 81-82.

Robinson, J.C. 1996. Bananas and Plantains. CAB Intl., Wallingford, U.K.

Robinson, J.C. and Nel, D. 1982. The use of banana bunch covers during summer at Burger shall. Burger shall Experimental Farm, South Africa. Information Bulletin, Citrus-and Subtropical Fruit Research Institute 118: 8-9.

Rodrigues, M.G.V., Souto, R.F. and Menegucci, J.L.P. 2001. Influence of polyethylene banana bunch cover for irrigated banana tree in the North of Minas Gerais state. Revista Brasileira de Fruticultura, 23: 559-562.

Scott, K.J., Wills, R.B.H., Rippon, L.E. 1971. The use of sealed polyethylene bunch covers during growth as a retardant to the 
ripening of bananas. Tropical Agric., 48: 163-165.

Seymour, G.B., Taylor, J.E. and Tucker, G.A. 1993. Biochemistry of fruit ripening Seymour G.B., (ed. Chapman and Hall, London, pp. 83-106.

Shanmugasundaran, K.A. and Manavalan, R.S.A. 2002. Postharvest characteristics of 'Rasthali' bananas grown under different polyethylene covers. Infomusa, 11(2):43-45.

Shewfelt, R.L. 2009. Measuring quality and maturity, In: Postharvest Handling - A systems approach. W.J. Florkowski, R.L. Shewfelt, B. Brueckner and S.E. Prussia (eds) Academic press, Inc. London, pp. 461-481.

Snowden, A.L. 2010. A colour atlas of postharvest disease and disorders of fruits and vegetables. Vol. 1, General introductions and fruits. Manson Publishing Ltd. UK.

Soto, M. 2010. Banano: Tecnologias de producción, Tomo II. Costa Rica.

Stevenson, D. 1976. What colour to select for banana bunch covers. Department of Agriculture, Coffs Harbour, NSW, Australia. Banana-Bulletin, 40: pp. 2- 4.

Stover, R.H. and Simmonds, N.W. 1987. Bananas. Third Edition, Longman, London. pp 67.

Trever, R.N. 2003. Bunch covers for bananas. Agri. Facts, 6: 1-2.
Trochoulias, T. 1975. Longevity of polyethylene bunch covers for bananas in relation to thickness of the film. Tropical Fruit Research Station, Alston Ville, NSW, Australia. Banana Bulletin, 52, pp. 281-283.

Turner, D.W. 1984. Bunch covers for bananas. Agfact H6.3.4 First edition. pp 78.

Turner, D.W. 2013. 'Crop physiology and cultural practices-a synergy in banana and plantain (Musa spp.)', International ISHS-ProMusa Symposium on Bananas and Plantains, Belgium, 986, pp. 41-50.

Vargas, A., Valle, H., González, M. 2010. Efecto del color y de la densidad del polietileno de fundas para cubrir el racimo sobre dimensiones, presentación y calidad poscosecha de frutos de banano y plátano. Agronomía Costarricense 34: 269-285. in Spanish, with abstract in English)

Vargas-Calvo, A. Valle-Ruiz, H. 2011. Effect of two banana (Musa AAA) bunch covers on fruit quality. Agronomía Mesoamericana, Vol. 22(1): 81-89.

Weerasinghe, S.S., and Ruwapathirana, K.H. 2002. "Influence of bagging material on bunch development of bananas (Musa spp.) under high density planting system." Annals of Sri Lankan Department of Agri., 4: 47-53.

\section{How to cite this article:}

Santosh, D.T., K.N. Tiwari and Raja Gopala Reddy. 2017. Banana Bunch Covers for Quality Banana Production - A Review. Int.J.Curr.Microbiol.App.Sci. 6(7): 1275-1291. doi: https://doi.org/10.20546/ijcmas.2017.607.155 